Kirja-arvio

\title{
Aineellisen ja aineettoman vuoropuhelua menneisyydessä ja nykyajassa
}

Alexandra Bergholm ja Riku Hämäläinen (toim.) 2018. Katse pyhään: Näkökulmia uskonnon aineellisuuteen. Helsinki: Kulttuuriosuuskunta Partuuna. 308 sivua.

\section{Tiina Mahlamäki}

$\mathrm{M}$ ateriaalisuuden ja aineellisuuden tarkastelu on viime vuosina noussut uskonnontutkimuksessa yhdeksi keskeiseksi lähestymistavaksi. Vaikka jo Ninian Smart aikanaan nosti määritelmässään materiaalisuuden yhdeksi uskonnon ulottuvuudeksi, vasta viime aikoina aihetta on uskontotieteen parissa ryhdytty vahvemmin teoretisoimaan ja pohtimaan analyyttisesti. Lähitieteissä, kuten antropologiassa, arkeologiassa tai kansatieteessä, aineellisuus on ollut itsestään selvä tarkastelukohde. Uskontotieteelliset tutkimukset hyödyntävät niissä kehitettyjä näkökulmia, mutta tuovat esiin myös uusia lähestymistapoja aineellisuuteen.

Uskontoperinteissä esineitä voi tarkastella vaikkapa toimijuuden näkökulmasta, jolloin artefaktilla voi olla omaa toimijuutta tai sen voidaan nähdä vahvistavan tai heikentävän ihmisen toimijuutta. Esineet tai luonnonmuodostelmat voi

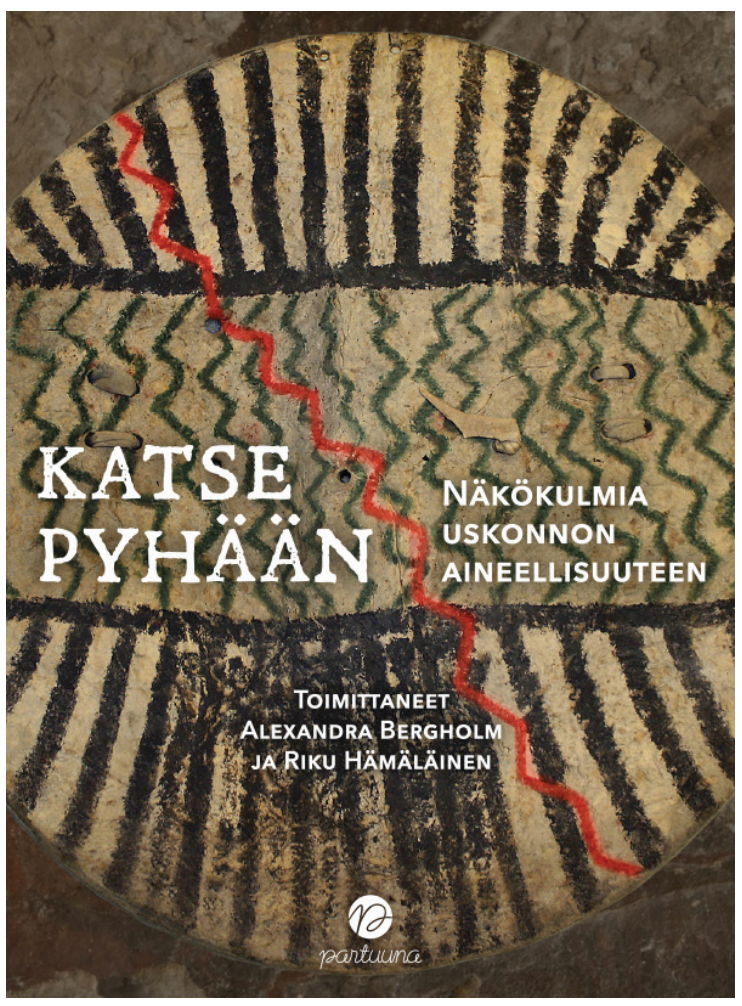
myös nähdä osana monimutkaisia, inhimillisistä ja ei-inhimillisistä toimijoista muodostuvia verkostoja Bruno Latourin (2007) ehdottamalla tavalla. Aineellisen ja aineettoman vuorovaikutus - kuten vaikkapa paikkojen, tilojen, esineiden ja rituaalien symbolimerkitys - on keskeinen uskontotieteen tutkimusasetelma, joka tässä artikkelikokoelmassa pääsee monipuoliseen käsittelyyn. 
Helsingin yliopiston uskontotieteen oppiaineen tuottaman, 14 artikkelista koostuvan kokoelman Katse pyhään. Näkökulmia uskonnon aineellisuuteen jokainen teksti lähtee liikkeelle konkreettisesta esineestä, esineryhmästä, kuvasta tai luonnonmuodostelmasta, ja kunkin historiallista ja kulttuurista kontekstia tarkastelemalla avautuu yksittäistä kohdetta laajempi ja syvällisempi kulttuurinen kuva.

Lukija oppii perusasioita hyvin monenlaisista ilmiöistä, traditioista ja tavoista, joten kokoelma on erittäin sivistävä. Tarkastelu kattaa kaikki mantereet ja keskeiset uskontoperinteet, mutta painopisteenä voidaan nähdä eletyn uskonnon huomioimisen. Jokaisella kirjoittajalla on oma teoreettinen näkökulmansa, mutta varsinaisia uuden materialismin teoreettisia sovelluksia kokoelmassa ei juurikaan hyödynnetä.

\section{Museoihin tallennetut esineet}

Kokoelman aloittaa Alexandra Bergholmin kuvaus Tanskan Jyllannista 1800-luvun lopulla löydetystä kelttiläiseksi ymmärretystä Gundestrupin padasta. Pata on tulkittu osaksi kelttiläistä kulttuuripiiriä, sillä siihen kuuluvien koristelaattojen kuvituksesta löytyy lukuisia kulttuurin piirteitä ja jumaluuksia. Bergholmin artikkelin fokuksena on se, miten pataa on eri aikoina ja eri näkökulmista tutkittu, mutta tutkimuksista huolimatta padan alkuperä ja käyttötarkoitus ovat jääneet arvoituksiksi - tai niistä on vähintäänkin useita erilaisia tulkintoja. Ehkä pataa koskevissa tutkimuksissa on lähdetty liikkeelle tutkijoiden omista esiymmärryksistä ja olettamuksista, jotka ovat voineet johtaa harhaan. Pata saattaakin kertoa enemmän eurooppalaisten kansojen kanssakäymisestä ja eri kulttuuripiirien rinnakkaiselosta kuin "kelttiläisestä rautakaudesta", kuten tähän asti on oletettu.

Gundestrupin pataa säilytetään Tanskan kansallismuseon aarteena, ja se oli Isossa-Britanniassa järjestetyn, kelttiläistä taidetta ja identiteettiä käsittelevän näyttelyn vetonaulana. Myös Riku Hämäläisen artikkelin käsittelemä Pohjois-Amerikan tasankointiaanin kilpi löytyi museosta: Stuttgartissa sijaitsevasta Linden-museosta. Kuvan kilpi toimii esimerkkinä tasankointiaani(miest)en tavasta rakentaa kilpensä näkyjen perusteella ja siitä, miten kilvet tarjoavat paitsi fyysistä myös yliluonnollista suojaa, rohtoa. Tämä on linjassa sen kanssa, miten tasankointiaanit eivät tee eroa uskonnon ja muun inhimillisen toiminnan välillä.

Riitta Korpelan artikkelin aiheena on Kansallismuseon kokoelmiin kuuluva raffini-kangas, joka edustaa alkuperäistä ja omaleimaista afrikkalaista käsityöperinnettä. Kankaat ovat olleet arvokkaita lahjoja ja maksuvälineitä. Miehet kutoivat kankaat, naiset koristelivat ne. Koristelu oli hidasta, aikaa vievää työtä, ja siksi sille omistautuivatkin vain ylhäisön naiset. Arvokkaita kankaita käytettiin juhla- ja rituaalitarkoituksissa, erityisesti hautajaisissa. 1800luvun lopulta lähtien kankaita on valmistettu ulkomaille myyntiin, mikä on taannut taitojen säilymisen ja rahan ansaitsemisen, mutta samalla kankaiden rituaalinen sekä valtaan sidottu merkitys on hiipunut.

Katja Ritari ottaa lähtökohdakseen Dublinin Trinity Collegen kirjastossa säilytettävän varhaiskeskiaikaisen Kellsin kirjan eli maailman kauneimmaksikin nimitetyn irlantilaismunkkien valmistaman käsikirjoituksen. Evankeliumitekstejä sisältävässä kirjassa tekstejä merkittävämmäksi nousee taidokas kuvitus ja koristelu. Noin vuonna 800 valmistetun kirjan 
kuvituksen on voitu katsoa syntyneen pyhimyksen tai enkelien tuella ja niiden katsomisen on nähty tarjoavan pilkahduksen taivaan autuudesta. Kirjoilla esineinä on voitu nähdä olevan yliluonnollisia, esimerkiksi parantavia tai säähän vaikuttavia, ominaisuuksia.

Mitra Härkösen tekstissä palataan taas Kansallismuseon kokoelmiin mutta siirrytään Aasiaan, sillä tarkasteltavana esineenä on taiteilija Per Steniuksen Intian ja Nepalin matkoillaan hankkima tiibetinbuddhalainen pyhä maalaus, mandala, jota on käytetty osana meditaatioharjoitusta. Itämaisesta henkisyydestä kiinnostuneita saattaa kiehtoa mandalan kuvakieli, mutta sen syvällisempi ymmärrys puuttuu. Tiibetinbuddhalaiselle mandala-kuvassa esiintyvät symbolit saavat henkisiä merkityksiä ja niitä meditoimalla inmiselle voi herätä tietoisuus omasta buddhaluonnosta. Mandala on siis malli henkiselle muutokselle ja valaistumiselle.

\section{Menneisyyden ja nykyisyyden vuoropuhelua}

Heikki Pesosen lähtökohtana ei ole ihmisen valmistama esine, vaan erityinen luonnonmuodostelma, joka on saanut uskonnollisen merkityksen: Australian Uluru, aboriginaalien pyhä vuori. Tekstin näkökulmana on kohtaaminen: vuoren erilaiset tulkinnat eri aikoina, alkuperäisasukkaiden ja nykypäivän turistien kohtaamiset, ihmisten ja yliluonnollisen kohtaamiset sekä yliluonnollisten olentojen keskinäiset kohtaamiset. Vaikka aboriginaaleja on asunut Australian mantereella jo 60000 vuotta, he saivat kansalaisoikeudet niinkin myöhään kuin 1967. Hiljalleen heidän oikeuksiaan on ryhdytty kunnioittamaan, esimerkiksi Ulurun alueella asuva kansa voi nykyään harjoittaa omaa kulttuuriaan sekä ansaita elantonsa turistioppaina. Aboriginaalit kertovat alueeseen liittyviä tarinoita ja haluavat turistien pikemminkin kokevan kuin katsovan paikkaa ja vangitsevan sen valokuviinsa.

Risto Pulkkisen šamaanin noitarumpua käsittelevä teksti lähtee yllättävästi liikkeelle postin vuonna 2012 julkaisemasta postimerkkiarkista, jonka kuvituksessa on käytetty saamelaisen noitarummun kalvon kuviointeja. Pulkkinen esittää yksityiskohtaisen tulkintaehdotuksen postimerkkiarkin keskellä olevan rummun kuvioinnista ja kertoo laajemminkin eri rumpumalleista ja niiden kuvioinneista.

Aila Viholainen jatkaa kuvien tulkintaa ottamalla lähtökohdakseen suomalaisen keskiaikaisen kirkon seinästä löytyvän merenneidon hahmon. Viholainen kuvaa merenneidon kulttuurihistoriaa alkaen Homeroksesta 300-luvulta ennen ajanlaskun alkua aina 2000-luvulle asti. Hattulan kirkon seinään 1400-luvulla maalattu merenneito tulkittiin 1800-luvun kansallismielisessä Suomessa osaksi kansallista kertomusta.

\section{Hengellisyyttä ja henkisyyttä}

Pyhän Athosvuoren Simonopetraksen luostarin ruokasalin seinästä löytyvä fresko, joka kuvaa kilvoittelijoiden nousua tikapuita pitkin kohti Kristusta, on René Gothonin artikkelin lähtökohta. Fresko liittyy erämaakilvoittelija Johannes Siinailaisen teokseen Portaat, jota ja jonka merkitystä ortodoksikristillisyydelle Gothoni artikkelissaan yksityiskohtaisesti avaa. Teksti myös kehottaa lukijaa pohtimaan omaa hengellistä kilvoitteluaan. 
Terhi Utriaisen enkelitalismaania käsittelevä artikkeli sijoittuu puolestaan uushenkisyyden sisään, enkeliuskon hybridiselle alueelle. Gothonin lähestymistapana on hermeneuttinen ymmärtämään pyrkiminen asettumalla vuorovaikutukseen oman kokemusmaailman ja tarkasteltavan kuvan välille. Utriainen puolestaan asettuu etnografin rooliin ja hyödyntää osallistuvaa havainnointia enkelihoitajakurssilla, jossa harjoitellaan enkelienergioiden hyödyntämistä parantamisessa ja jonka lopussa valmistetaan mukana kuljetettava, onnea tuova enkelitalismani.

Utriaisella on vahva teoreettinen ote, mikä mahdollistaa sen, että pieni esine ja sen valmistamisen lyhyt kuvaus tarjoavat mahdollisuuden tarkastella niin enkelien historiaa eri uskontoperinteissä, uskonnonharjoittamisen tai eletyn uskonnon materiaalisuutta ja aistillisuutta kuin erilaisia tulkintoja oikeista ja vääristä tavoista kommunikoida näkymättömän maailman kanssa.

\section{Arjessa elettyä uskonnollisuutta}

Tuula Sakaranahon artikkelissa siirrytään islamin maailmaan, mutta jatketaan teemassa, jossa esineitä käytetään amuletteina tai talismaneina. Islamilaisessa arjen uskonnollisuudessa on yleistä käyttää eri esineisiin tai alustoille kirjoitettuja Koraanin jakeita suojaksi pahaa vastaan, tuomassa turvaa tai rukouksena kodin seinällä, auton tuulilasissa tai vaatteiden sisällä. Koska islamissa suhtaudutaan kuviin kielteisesti, on teksteillä ja kalligrafialla sitä suurempi merkitys. Artikkeli välittää hyvin ja monipuolisesti Koraanin ja sen tekstien merkityksen kansanomaisessa uskonnollisuudessa sekä sen, miten vahvasti kuuloaisti painottuu islamissa.

Erityisesti länsimaissa on viime vuosina kiinnitetty paljon huomiota musliminaisten käyttämiin huntuihin. Useimmiten huntujen käyttöä halutaan rajoittaa vedoten musliminaisten itsemääräämisoikeuteen, työsuojeluun tai uskonnonvapauteen. Johanna Konttorin artikkeli esittelee monipuolisesti hunnuttautumisen moninaisuutta sekä hunnunkäytölle annettuja merkityksiä. Artikkeli kertoo myös siitä, miksi musliminaisen hunnuista on tullut niin merkittävä kiistakysymys Euroopassa ja siitä, että hunnunkäytöstä harvemmin kysytään muslimeilta itseltään tai niiltä naisilta, jotka huntua käyttävät.

Ira Multaharjun artikkelissa siirrytään Etelä-Amerikkaan ja afrobrasilialaiseen kulttuuriin. Lähtökohtana ei ole yksi esine vaan esinekokoelma: vaatetettu naishahmo, malja, käsipeili, helmiä, parfyymipullo, saviastia ja rummunkalvo. Esineet kuuluvat kirjoittajalle itselleen ja hän on koonnut ne asetelmaksi brasilialaisen mallin mukaan. Artikkeli tarjoaa kuvauksen afroamerikkalaisesta, synkretistisestä uskontoperinteestä, sen symboliikasta ja kirjoittajan oman tulkinnan symbolien merkityksestä nykyajassa.

Artikkelikokoelman päättää Riikka Uuksulaisen teksti, jonka lähtökohtana on Intian Kolkatasta ostettu jumalatar Äiti Shasthin patsas. Se voi näyttää koriste-esineeltä, mutta palvojan käytössä siitä tulee elävän jumalattaren materiaalinen kuva. Jumalatar voi patsaan lisäksi ilmentyä monissa yksinkertaisissakin esineissä, kuten savihahmoissa, puunkappaleissa tai lehmän pääkallossa. Shasthi on hedelmällisyyden jumalatar, jolta rukoillaan lapsia ja suojelusta jo syntyneille lapsille, jotta nämä pysyisivät terveinä ja hengissä. Rukoilun yhteydessä 
saatetaan tehdä lupaus vastapalveluksesta, jos pyyntö toteutuu. Joskus rukoilija tulee luvanneeksi liikaa ja on vaikeuksissa yrittäessään toteuttaa lupauksensa.

\section{Materiaalisuus maailman uskontoperinteissä}

Artikkelikokoelman painopiste on maailman uskontoperinteissä; esimerkkejä on tarjolla kaikista maanosista. Painopiste on myös historiallisessa kontekstissa: monet käsitellyt esineet löytyvät museoista, ne on valmistettu tai syntyneet kaukaisessa menneisyydessä ja niillä on pitkä historia. Myös nykypäivän esineet asettuvat osaksi historiallista jatkumoa.

Teos on kirjoitettu hyvällä, yleistajuisella kielellä, joten sen artikkeleita voi mainiosti käyttää vaikkapa lukio-opetuksessa tai perustason yliopisto-opetuksessa syventämässä jotain käsiteltävää teemaa. Se avautuu kaikille aiheesta kiinnostuneille ja on kauniisti taitettu.

Teoksen keskeinen opetus liittyy kulttuurien kohtaamiseen ja synkretismiin: mikään kulttuuri ei elä loputtomiin eristyksissä vaan on aina suhteessa toisiin kulttuureihin - joskus vapaaehtoisesti, joskus pakotettuna. Kulttuurit kehittyvät ja muuttuvat näissä kohtaamisissa.

\section{Kirjallisuus}

Latour, Bruno. (2007). Reassembling the Social: An Introduction to Actor-Network Theory. Oxford: Oxford University Press.

Filosofian tohtori, dosentti Tiina Mahlamäki on uskontotieteen yliopistonlehtori Turun yliopiston historian, kulttuurin ja taiteiden tutkimuksen laitoksella. 